\title{
Assessment of Planting Methods in Bidi Tobacco (Nicotiana tabacum L.) to Minimize the Effect of Water Logging under Rainfed Conditions in Vertisols of Andhra Pradesh, India
}

\author{
S. Jaffar Basha ${ }^{1}$, J. Manjunath ${ }^{1}$, P. Pulli Bai ${ }^{1}$ and C. Chandrasekhara Rao ${ }^{2}$ \\ ${ }^{1}$ Regional Agricultural Research Station, Acharya N.G. Ranga Agricultural University \\ Nandyal-51850, Kurnool District, Andhra Pradesh, India \\ ${ }^{2}$ All India Network Project on Tobacco, Central Tobacco Research Institute, Rajahmundry, \\ Andhra Pradesh, India \\ *Corresponding author
}

\begin{tabular}{|l|}
\hline Ke y w o r d s \\
Ridge planting, \\
Planting geometry, \\
Cured leaf yield, \\
Economics, Leaf \\
quality
\end{tabular}

A B S T R A C T

A field experiment was undertaken at Regional Agriculture Research Station, Nandyal, Andhra Pradesh during 2017-18 on vertisols under rainfed condition to find out the suitable method of planting to avoid water logging for higher cured leaf yield in bidi tobacco (Nicotiana tabacum L.). The treatments consisted of two planting methods (Ridge method and flat bed method) as one factor and four planting geometry $(60 \mathrm{~cm} \times 50 \mathrm{~cm}, 60$ $\mathrm{cm} \times 75 \mathrm{~cm}, 75 \mathrm{~cm} \times 50 \mathrm{~cm}$ and $75 \mathrm{~cm} \times 75 \mathrm{~cm}$ ) as another factor in factorial randomized block design and replicated thrice. The bidi tobacco variety used for experimentation is Nandyal Pogaku-1. Soil moisture was higher under ridge method when compared to flat method at all intervals except at 45 DAP. SPAD readings recorded do not show significant changes due to different treatments except variation in readings at different intervals. Ridge planting method recorded significantly higher leaf length $(39.0 \mathrm{~cm})$, leaf width $(14.3$ $\mathrm{cm})$, cured leaf yield $\left(1550 \mathrm{~kg} \mathrm{ha}^{-1}\right)$ against flat bed method planting $(37.3 \mathrm{~cm}, 13.5 \mathrm{~cm}$ and $\left.1359 \mathrm{~kg} \mathrm{ha}^{-1}\right)$. Significantly higher cured leaf yield was recorded with $60 \mathrm{~cm} \mathrm{x} 75 \mathrm{~cm}$ $\left(1521 \mathrm{~kg} \mathrm{ha}^{-1}\right)$ was on par with $75 \mathrm{~cm} \mathrm{x} 50 \mathrm{~cm}\left(1490 \mathrm{~kg} \mathrm{ha}^{-1}\right)$ and $75 \mathrm{~cm} \mathrm{x} 75 \mathrm{~cm}(1423 \mathrm{~kg}$ $\left.\mathrm{ha}^{-1}\right)$. Higher leaf length $\left.39.8 \mathrm{~cm}\right)$ and leaf width $(15.0 \mathrm{~cm})$ was observed at $75 \mathrm{x} 75 \mathrm{~cm}$ planting. Interaction effect with planting method and spacing found non significant. Higher net returns was observed in ridge method (Rs 79,225/ ha) with BCR of 2.77 whereas planting at $60 \mathrm{~cm} \times 75 \mathrm{~cm}$ geometry recorded net returns of Rs $78,405 /$ ha with BCR of 2.81 .

\section{Introduction}

Tobacco (Nicotiana tabacum L.) is the most important non-food crop cultivated in more than 100 countries. It is one of the most important commercial crops of India, valued for its leaf containing nicotine. It is grown over an area of 0.46 million ha with production of 0.84 million tones with productivity of $1842 \mathrm{~kg} / \mathrm{ha}$ (Agriculture statistics at a glance 2016 at www.agricoop.nic.in \& http:// 
eands.dacnet.nic.in). In Andhra Pradesh, bidi tobacco is commercially cultivated under rainfed black soils in late rainy season i.e., September ( $2^{\text {nd }}$ fortnight) month. The rainfed agriculture suffers from a number of hydrophysical and socio-economic constraints, which affect the productivity of rainy and post-rainy season crops. These include erratic and undependable rainfall, excess and deficient moisture within a season, harsh thermal regime, soil loss, low level of input use and technology adoption and resource poor farmers (Gupta, 2002). After few showers the monsoon rains in July - August and September are usually heavy and frequent. Under such situation water logging is a common problem which affects early growth, root proliferation and final yield performance of crop. Extreme variability in the quantity, time and duration of rains expose the soybean crop to soil moisture deficit as well as excess moisture either on account of delayed monsoon, longer dry spells or early withdrawal mansoon has been identified as one of the major factors for poor performance of soybean crops (Tiwari, 2014; Gupta et. al., 2018). Studies on soil management for increasing crop production revealed that use of various tillage methods and modification of land configurations such as broad bed furrow, ridges and furrow for soybean in vertisols were superior over flat bed and recommended in watershed development for moisture conservation as well as for safe removal of excess rain water (Raut and Taware, 1997). There is a need for in-situ soil and water conservation and proper drainage technology in black soils. This technology has many advantages including in-situ conservation of rainwater in furrows, better drainage of excess water and proper aeration in the ridge and root zone. Besides, other techniques the In-situ conservation of rainwater at farm level by adopting holistic approach to the management of rainwater like broad-bed and furrow, ridge and furrow, tied ridging, raised and sunken bed and compartmental bunding etc. by which crop productivity is substantially increased. Land treatments (raised sunken bed system, ridges and furrows, broad bed and furrows) increased in situ soil moisture conservation, minimized runoff, and soil erosion (Nagavallemma et al., 2005). Hari Ram et al., 2012 concluded that raised bed, raised broad bed and ridge furrow sowing of soybean should be advocated over flatbed sowing mainly due to their ability to save irrigation water. Plant spacing is required for the optimum yield. Closer spacing of plants resulted in reduction of size, body, thickness and weight per unit area of the leaf, Price of tobacco grown at higher plant densities was also lower, resulting in lower income from such production observed a decrease in total leaf area per plant with increased plant population Bukan et al., (2010). Regulate the optimal density is one of the important factors to get the maximum yield due to the climatic conditions of each region and specifications of varieties are cultivated. Alizadeh et al., (2013) studied the effect of plant spacing on tobacco yield of Barley variety. They observed that there is a negative relationship between plant spacing and yield. In view of the above fact the study was undertaken to find out the suitable method of planting to avoid water logging for higher cured leaf yield of bidi tobacco.

\section{Materials and Methods}

A field experiment was undertaken at Regional Agriculture Research Station, Nandyal, Andhra Pradesh during 2017-18 on vertisols under rainfed condition to find out the suitable method of planting to avoid water logging for higher cured leaf yield of bidi tobacco (Nicotiana tabacum L.). The soil of experimental site was medium deep black, moderately alkaline (pH-8.2), non saline (EC$0.11 \mathrm{ds} / \mathrm{m})$, low in nitrogen $\left(152.3 \mathrm{~kg} \mathrm{ha}^{-1}\right)$, medium in available $\mathrm{P}_{2} \mathrm{O}_{5}\left(32.5 \mathrm{~kg} \mathrm{ha}^{-1}\right)$ and 
high in available $\mathrm{K}_{2} \mathrm{O}\left(350.9 \mathrm{~kg} \mathrm{ha}^{-1}\right)$. The treatments consisted of two planting methods (Ridge method and flat bed method) as one factor and four planting geometry $(60 \mathrm{~cm} \times 50$ $\mathrm{cm}, 60 \mathrm{~cm} \times 75 \mathrm{~cm}, 75 \mathrm{~cm} \times 50 \mathrm{~cm}$ and $75 \mathrm{~cm}$ $x 75 \mathrm{~cm}$ ) as another factor in factorial randomized block design and replicated thrice. The bidi tobacco variety used for experimentation is Nandyal Pogaku-1. Crop management practices like land preparation, $\mathrm{N}, \mathrm{P}$ and $\mathrm{K}$ fertilizer application, weed control, intercultivation, need based plant protection, de suckering and sun curing were followed as recommended for local area. The nursery was raised on 26-07-17 and healthy seedlings were transplanted on 14-09-17. The crop was harvested on 06-02-18. The experiment was conducted under rainfed condition. An amount of $519.6 \mathrm{~mm}$ of rainfall was received during crop season (July to December) during 2017. Rainfall distribution was highly erratic coupled with prolonged dry spells i.e. $307 \mathrm{~mm}$ in 17 rainy days in nursery and $212.6 \mathrm{~mm}$ in 13 rainy days in standing crop after transplanting. The data were recorded on soil moisture and quantitative traits such as plant height, leaf length, leaf width and cured leaf yield at harvest. Leaf quality parameters like nicotine and reducing sugars were analysed at CTRI, Rajahmundry. The mean values of all the quantitative characters were subjected to statistical analysis by adopting Fisher's method of analysis of variance as outlined by Gomez and Gomez (1984). The level of significance used in ' $F$ ' test was at 5 per cent.

\section{Results and Discussion}

\section{Soil moisture}

Soil moisture was higher under ridge method $(19.6 \%, 24.7 \%, 14.3 \%$ and $12.6 \%$ at 15 DAP, 30 DAP, 60 DAP and 90 DAP) when compared to flat method $(17.6 \%, 21.2 \%$, $12.1 \%$ and $10.6 \%$ at $15 \mathrm{DAP}, 30 \mathrm{DAP}, 60$ DAP and 90 DAP) at all intervals except at 45 DAP (Table 1 and Fig. 1.).

Table.1 Effect of planting methods and planting geometry on soil moisture in bidi tobacco

\begin{tabular}{|l|c|c|c|c|c|}
\hline \multicolumn{1}{|c|}{ Treatment } & \multicolumn{5}{c|}{ Soil moisture (\%) } \\
\cline { 2 - 6 } & 15 DAP & 30 DAP & $\mathbf{4 5}$ DAP & 60 DAP & 90 DAP \\
\hline Planting methods & & & & & \\
\hline Ridge method & 19.6 & 24.7 & 17.1 & 14.3 & 12.6 \\
\hline Flat method & 17.6 & 21.2 & 15.7 & 12.1 & 10.6 \\
\hline S.Em \pm & 0.43 & 0.67 & 0.61 & 0.40 & 0.43 \\
\hline C.D.(P=0.05) & 1.3 & 2.0 & NS & 1.2 & 1.3 \\
\hline Planting geometry & & & & & \\
\hline 60cmx50cm & 18.1 & 22.3 & 15.9 & 12.8 & 11.4 \\
\hline 60cmx75cm & 18.5 & 22.8 & 15.9 & 13.2 & 11.3 \\
\hline $\mathbf{7 5 c m x 5 0 c m}$ & 18.4 & 23.1 & 16.8 & 13.3 & 11.3 \\
\hline 75cmx75cm & 19.5 & 23.7 & 17.0 & 13.3 & 12.3 \\
\hline S.Em \pm & 0.61 & 0.95 & 0.86 & 0.57 & 0.61 \\
\hline C.D.(P=0.05) & NS & NS & NS & NS & NS \\
\hline Interaction & NS & NS & NS & NS & NS \\
\hline
\end{tabular}


Table.2 Assessment of planting methods and planting geometry on growth, cured leaf yield, economics and leaf quality of bidi tobacco

\begin{tabular}{|c|c|c|c|c|c|c|c|c|c|c|}
\hline Treatments & $\begin{array}{c}\text { Plant } \\
\text { height } \\
(\mathrm{cm})\end{array}$ & $\begin{array}{c}\text { Leaf } \\
\text { length } \\
(\mathbf{c m})\end{array}$ & $\begin{array}{c}\text { Leaf } \\
\text { width } \\
\text { (cm) }\end{array}$ & $\begin{array}{c}\text { Cured leaf } \\
\text { yield } \\
\text { (kg/ha) }\end{array}$ & $\begin{array}{c}\text { Gross } \\
\text { returns } \\
\text { (Rs/ha) }\end{array}$ & $\begin{array}{c}\text { Cost of } \\
\text { cultivation } \\
\text { (Rs/ha) }\end{array}$ & $\begin{array}{c}\text { Net } \\
\text { returns } \\
\text { (Rs/ha) }\end{array}$ & BCR & $\begin{array}{c}\text { Nicotine } \\
(\%)\end{array}$ & $\begin{array}{c}\text { Reducing } \\
\text { sugars } \\
(\%)\end{array}$ \\
\hline \multicolumn{11}{|l|}{ Planting methods } \\
\hline Ridge method & 52.1 & 39.0 & 14.3 & 1550 & 124000 & 44775 & 79225 & 2.77 & 4.68 & 2.59 \\
\hline Flat method & 46.3 & 37.3 & 13.5 & 1359 & 108720 & 42775 & 65945 & 2.54 & 4.33 & 2.62 \\
\hline S.Em \pm & 2.28 & 0.16 & 0.08 & 25.7 & & & & & 0.17 & 0.11 \\
\hline C.D. $(\bar{P}=0.05)$ & NS & 0.50 & 0.2 & 80 & & & & & NS & NS \\
\hline \multicolumn{11}{|l|}{ Planting geometry } \\
\hline $60 \mathrm{~cm} \times 50 \mathrm{~cm}$ & 42.9 & 36.6 & 12.9 & 1383 & 110640 & 43775 & 66865 & 2.53 & 4.71 & 2.64 \\
\hline $60 \mathrm{~cm} \times 75 \mathrm{~cm}$ & 47.6 & 37.8 & 13.4 & 1521 & 121680 & 43275 & 78405 & 2.81 & 4.39 & 2.52 \\
\hline $75 \mathrm{~cm} \times 50 \mathrm{~cm}$ & 51.5 & 38.4 & 14.2 & 1490 & 119200 & 43475 & 75725 & 2.74 & 4.61 & 2.56 \\
\hline $75 \mathrm{~cm} \times 75 \mathrm{~cm}$ & 54.8 & 39.8 & 15.0 & 1423 & 113840 & 42775 & 71065 & 2.66 & 4.33 & 2.70 \\
\hline S.Em \pm & 3.22 & 0.23 & 0.11 & 35.3 & & & & & 0.25 & 0.14 \\
\hline C.D. $(\bar{P}=0.05)$ & NS & 0.71 & 0.3 & 105 & & & & & NS & NS \\
\hline Interaction & NS & NS & NS & NS & & & & & NS & NS \\
\hline
\end{tabular}


Fig.1

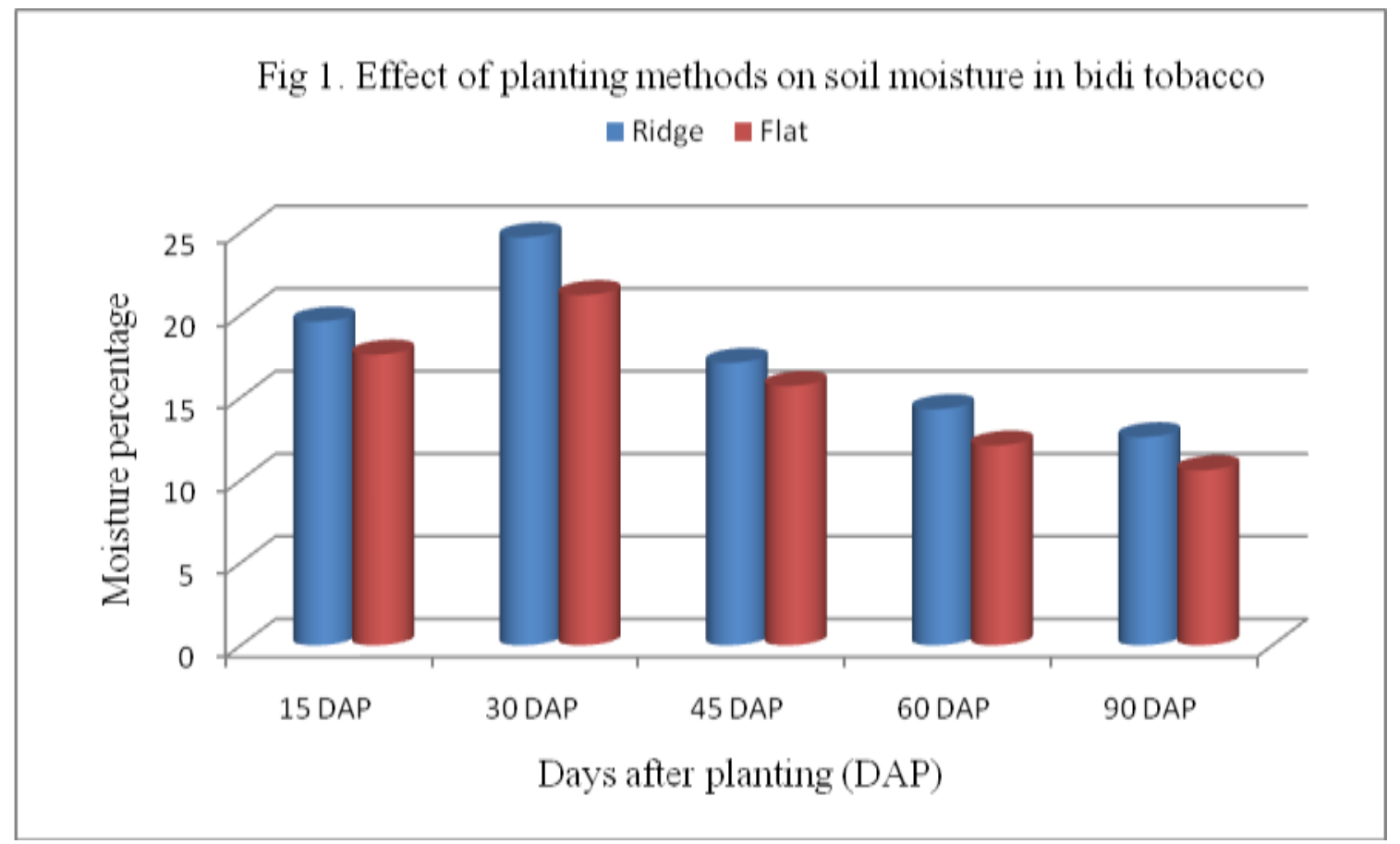

No significant change in soil moisture among different spacings at different intervals. Comparatively higher moisture was recorded with plant geometry of $75 \mathrm{~cm} \mathrm{x} 75 \mathrm{~cm}$ whereas lower moisture was recorded with 60 $\mathrm{cm} \times 50 \mathrm{~cm}$.

\section{Planting methods}

Plant height did not differed with planting methods (Table 2). Ridge planting method recorded significantly higher leaf length (39.0 $\mathrm{cm})$, leaf width $(14.3 \mathrm{~cm})$, cured leaf yield $\left(1550 \mathrm{~kg} \mathrm{ha}^{-1}\right.$ ) against flat bed method planting $\left(37.3 \mathrm{~cm}, 13.5 \mathrm{~cm}\right.$ and $\left.1359 \mathrm{~kg} \mathrm{ha}^{-1}\right)$. Ram et al., (2011) also concluded that ridge and furrow sowing of soybean should be advocated over flatbed sowing mainly due to their ability to save irrigation water.

Kumari and Rao (2005) reported that the crop growth rate and net assimilation rate were higher when crops are planted on ridge and furrow or bed planting system for mustard. Jadav et al., (2012) and Dhakad et al., (2015) found higher growth parameters, yield and yield attributes parameters in ridge and furrow system over flat sowing system in soybean. Similar trends reported by Bhargav et al., (2013).

\section{Planting geometry}

Plant height did not differed with planting geometry (Table 2). Significantly higher leaf length $(39.8 \mathrm{~cm})$ and leaf width $(15.0 \mathrm{~cm})$ was recorded with plant geometry of $75 \mathrm{~cm} \times 75$ $\mathrm{cm}$ whereas lower leaf length $(36.6 \mathrm{~cm})$ and leaf width $(12.9 \mathrm{~cm})$ was recorded with plant geometry of $60 \mathrm{~cm} \times 50 \mathrm{~cm}$. Significantly higher cured leaf yield was recorded with 60 $\mathrm{cm} \times 75 \mathrm{~cm}\left(1521 \mathrm{~kg} \mathrm{ha}^{-1}\right)$ was at par with 75 $\mathrm{cm} \times 50 \mathrm{~cm}\left(1490 \mathrm{~kg} \mathrm{ha}^{-1}\right)$ and $75 \mathrm{~cm} \mathrm{x} 75 \mathrm{~cm}$ $\left(1423 \mathrm{~kg} \mathrm{ha}^{-1}\right)$. Interaction effect with planting method and spacing found non significant. The possible reason for this could be due to the genetic adoptability of tobacco hybrids to T3 spatial arrangement Kharazmi et al., (2014) and also similar results were reported by Bukan et al., (2010). 


\section{Economics}

Higher net returns (Rs 79,225/ ha) with BCR of 2.77 was observed in ridge method and in planting at $60 \times 75 \mathrm{~cm}$ spacing (Rs 78,405/ha and BCR of 2.81). Similar results reported by Bhargav et al., (2013) and Dhakad et al., (2015). They concluded that the higher gross as well as net monetary returns were recorded under ridge and furrow planting as compared conventional system.

\section{Leaf quality parameters}

Leaf nicotine and reducing sugars did not differed with treatments and are in permissible limits.

In conclusion, bidi tobacco planting at plant geometry of $60 \times 75 \mathrm{~cm}$ under ridge planting is optimum for higher moisture conservation, cured leaf yield, leaf quality and net returns.

\section{Acknowledgement}

The authors are grateful to All India Network Project on Tobacco (AINPT), ICAR-CTRI, Rajahmundry and Regional Agricultural Research Station, Nandyal, ANGRAU, Andhra Pradesh for providing the facilities for smooth conduct of the experiment.

\section{References}

Agricultural Statistics at a Glance, 2016, Directorate of Economics and Statistics, Ministry of Agri., Govt. of India (http://www.dacnet.nic.in/ean.).

Alizadeh, R., Roshdi, M., Jalili, F., Rezadoost, S., Khalili M. J. and Alizadeh, F. 2013, The Effect of Ammonium Nitrate and Plant Density on Yield and Vegetative Characteristics of Burley Tobacco (Nicotiana tabacum L.) Variety No. 21. Advances in Environmental Biology, 7(1): 16-22.
Bhargav, K. S., Jain, V.K. and Umat, R., 2013, Ridge and furrow system of planting seeds: A water management approach for increased soybean production in Madhya Pradesh. Journal of Interacademicia 17(2): 245-253.

Bukan, M., Budimir, A., Boic, M., Sarcevic, H. and V Kozumplik, V., 2010, Effect of Within-Row Spacing on Agronomic and Morphological Characteristics of the Flue-Cured Tobacco Cultivars. $J$ Agric Conspec sci 75(1): 27-31.

Dhakad, S. S., Badaya, A.K., Chauhan, S. S. and Gathiye, G.S., 2015, Effect of ridge and furrow system on the growth character and yield in rainfed soybean in Madhya Pradesh. Indian Journal of ecology, 42(1): 230-232.

Gomez, K. A. and Gomez, A. A. 1984. Statistical Procedures for Agricultural Research. 2nd Ed. John Wiley \& Sons, New York. 207-215.

Gupta, R. K., 2002, National resources conservation technologies for black clay soil region of Peninsular India. Journal of Indian Society of Soil Science 50(4): 438-447.

Gupta, R., Kulmi, G.S., Basediya, A.L. and Mohan, J., 2018, Influence of furrow irrigated raosed bed seed drill on growth characteristics and yield of soybean in Mandsaur district of Madhya Pradesh, India. Plant Archives 18(1): 320-324.

Hari Ram, Guriqbal, S., Navneet, A. and Jagmeet, K., 2012, Soybean (Glycine max) growth, productivity and water use under different sowing methods and seeding rates in Punjab. Indian Journal of Agronomy, 56 (4): 377-380.

Jadhav, J. A., Patil, D B. and Ingole, P. G., 2012, Effect of mechanization with different land configuration on yield and in situ moisture conservation of soybean. Internat. J. agric. Sci., 8(1): 48-51.

Kharazmi, S., Taghizadeh, R., Vahedi, A., 
2014, Investigate the effect of planting and densities pattern on quantitative and Qualitative Characteristics Virginia Tobacco (Coker 347) in the west Region Gilan-Talesh. Indian J of Fund and Applied Life Sci., 4(3): 598-603.

Kumari, C. R. and Rao, D. S. K., 2005, Effect of land treatments and dates of sowing on growth parameters of mustard (Brassica juncea L.). J. Oilseeds Research 22(1): 188-189.

Nagavallemma, K. P., Wani, S. P., Reddy, M. S. and Pathak, P., 2005, Effect of landform and soil depth on productivity of soybean based cropping systems and erosion losses in Vertic Inceptisols. Ind. J. Soil Conservation, 33(2): 132-136.

Ram, H., Singh, G., Aggarwal, N. and Jagmeet, K., 2011, Soybean (Glycine max) growth, productivity and water use under different sowing methods and seeding rates in Punjab. Indian Journal of Agronomy, 56 (4): 377-380.

Raut, V. M. and Taware, S.P., 1997, Comparison of different sowing methods in soybean. J. Maharashtra Agric. Univ., 25 (2): 218-219.

Tiwari, S.P., 2014, Raising the yield ceiling in soybean. An Indian overview. Soybean Research, 12(2): 1-43.

\section{How to cite this article:}

Jaffar Basha, S., J. Manjunath, P. Pulli Bai and Chandrasekhara Rao, C. 2019. Assessment of Planting Methods in Bidi Tobacco (Nicotiana tabacum L.) to Minimize the Effect of Water Logging under Rainfed Conditions in Vertisols of Andhra Pradesh, India. Int.J.Curr.Microbiol.App.Sci. 8(01): 846-852. doi: https://doi.org/10.20546/ijcmas.2019.801.092 